SHS Web of Conferences 10, 00019 (2014)

DOI: $10.1051 /$ shsconf/20141000019

C Owned by the authors, published by EDP Sciences, 2014

\title{
The understanding of co-owners' rights in the context of the genesis of environmental rights
}

\author{
I. Kudeikina \\ Rīga Stradinsš University, Latvia
}

\begin{abstract}
Environmental rights obtain a special importance in the context of real distribution of joint property. The common practice, where the building regulations are applied to legal relationships when carrying out the real distribution of a joint property, is associated with the genesis of environmental rights, but cannot be supported by the doctrine of absolutism of the property rights. In this Article, the author analyzes the legal reasoning and legal consequences of applicability of environmental rights. The essence of real distribution of joint property is the termination of the joint property as a legal act without a target of environmental transformation. The real distribution of joint property is not an action leaving any environmental impacts. The author concludes that the application of the environmental rights to the real distribution of the joint property unreasonably limits the property rights of co-owners.
\end{abstract}

\section{Target and methods}

The aim of this article is to explore the scope of rights of co-owners and possibilities of their implementation in the context of genesis of environmental rights. The tasks set to achieve the objectives are the study of the policy planning documents, legislative analysis and case studies.

To achieve the objectives, the research methods used were the grammatical method and the systematic method to identify the conceptual content of the laws and regulations and court rulings, and the analytical method to analyse the data obtained and to draw qualitatively new conclusions.

With the development of society understanding of property as a physical object, as well as understanding of rights in the context of the property rights, undergo metamorphosis. Property is acknowledged as untouchable, and the right to property is recognized as a fundamental right protected by the laws and regulations of the highest legal force - the Universal Declaration of Human Rights (Article 17), the Protocol I (Article 1) of the Convention for the Protection of Human Rights and Fundamental Freedoms, the Constitution of the Republic of Latvia (Article 105). In addition, relevant provisions have been incorporated in many laws relating to socio-environmental relationships.

Property as an object of material nature and property right (being intangible itself) as a regulator of the object of material nature are human values.

In the middle of the $20^{\text {th }}$ century, a field of law, such as environmental rights, emerges and rapidly develops, dealing with the environment and man in it, human activities with environmental objects as the objects of regulation. It should be noted that, contrary to the property rights, which are private, the

This is an Open Access article distributed under the terms of the Creative Commons Attribution License 4.0, which permits unrestricted use, distribution, and reproduction in any medium, provided the original work is properly cited. 


\section{SHS Web of Conferences}

environmental rights are public rights. Article 115 of the Constitution of the Republic of Latvia provides that the State shall protect the right of everyone to live in a benevolent environment by providing information on the condition of the environment and taking care of its maintenance and improvement. Environmental conservation is a national responsibility. The Environmental Protection Law entered into force on 29 November, 2006 with the aim to "provide for the conservation and recovery of the quality of environment, as well as the sustainable use of natural resources."

The right for the environment (uncontaminated, etc.) has been declared as a value in the laws and regulations. But what is the attitude of society, owners and commercial operators?

Every individual legal entity wishes to gain the maximum benefit from his/her property. In a joint property the content of ownership rights is distributed among multiple legal entities, and in order to implement one's individual rights fully, the termination of joint ownership has been provided for, involving its real distribution. How the environmental rights affect the rights of co-owners?

Analyzing the content of property rights, one can conclude that the right does not require from the owner to preserve the object of the property and does not require usage of it so that it would be possible to leave it to the future generations. The ultimate goal of environmental rights is to ensure the preservation of natural resources for the future generations. How to balance the benefits of property rights with the responsibilities of environmental rights? What is the legal or ethical basis to look at the co-owners rights for distribution of the joint property through the lens of environmental rights?

With the development of society, the understanding of the property as a physical object and hence understanding of the property rights, developed. The modern understanding of the property rights is known since the works of the Ancient Roman lawyers. The concept of property rights is so extensive that the features of property tights cannot be given. Article 927 of the Civil Code provides that "Ownership is the full right of control over property, i.e., the right to possess and use it, obtain all possible benefit from it, dispose of it and, in accordance with prescribed procedures, claim its return from any third person by way of an ownership action."

Real estate (including land) is one of the major public economic values, the use of which affects each individual's financial well-being.

Each individual legal entity wishes to gain the maximum benefit from his/her property, fully utilizing the property rights. It is a legitimate right. But the content of property rights does not ensure the owner's responsibility to preserve the object of property, and to use it and to leave it to the future generations. This raises the question of how to reconcile the often differing interests of various entities with the needs and interests of general public (the state)?

The real distribution of joint property is a legal private act, where the co-owners in their coherent expression of will have to take into account, however the priorities of the public. This results from the Land Survey Law adopted on 14.09.2006. In accordance with Section 3, Clause 8, the land use planning project is to be developed also for distribution units of land in a co-ownership. With the aim of promoting the land property improvement, the law contains such requirements, which are not provided by the Civil Code in reference to the real distribution of property. The mutual continuity and supplement between legal norms cannot be found, because the property was originally a private institute, which would require some references and links to the Civil Law.

One of the instruments for aligning the individual and community interests is the spatial planning. By Section 2 of the Law "Spatial Development Planning Law" of 13.10.2011, it was set out that "spatial development is planned in such a way that would raise the environmental quality, ensure sustainable, effective and rational utilisation of territories and other resources, as well as purposeful and balanced development of economy." It is the detail planning that is to be recognized as one of the main instruments ensuring that the public and governmental interests in usage of a particular territory are duly coordinated with the interests of particular owner of real estate. The Constitutional Court of the Republic of Latvia 


\section{Int. Conf. SOCIETY. HEALTH. WELFARE.}

repeatedly stated that in its judgments about the conformity of the spatial planning documents with the Latvian Constitution of the Republic of Latvia. ${ }^{1}$

As professor Ilma Čepāne pointed out, "not understanding the meaning of sustainable development, the requirements in the field of environmental protection may be disproportionately reduced for the purposes of economic interests" (Čepāne, 2011). Opposing this view, it should be emphasized that by beholding the property only as an object of economic activity, regardless of property rights as an absolute value, the co-owners' rights are reduced unreasonably.

The grammatical and the systemic interpreting of those laws and regulations relating to distribution of the real estate, in view of environmental rights, it is evident that environmental laws are aimed at the regulation of construction (as an environmentally transformative action).

Thus, in accordance with Regulation No. 496 "Classification of the targets as to the use of real estate and Order of detection and change of targets of the use of real estate" of 20.06.2006 of the Cabinet of Ministers, the land use can be divided into two main groups:

1) The land on which building is not the primary land use - building is permitted in cases where it is necessary for the purposes of the permitted use;

2) land for building.

The grammatical analysis of the legal provision supports the conclusion that the distribution is based on building (its possibility or ban). All lands are divided into those, on which building is possible and those on which it is not. The division of land is made on the basis of its economic usability.

The legal target of the distribution of the joint property is to terminate the joint property, not addressing the issue of land development, where the legal framework of environmental rights would be supported.

Planning of measures for environmental protection has been set as a responsibility of the local governments. Thus, the first paragraph of Article 7 of the Law "On Local Governments" states that the municipal council has the right to issue binding regulations on the city's or county's land use. So, regulatory rules and requirements for building that affect and apply also to real property distribution may differ in every republican city or municipality. Various municipalities, for example, have laid down different minimum parcel size and, consequently, in case of a real distribution co-owners are in different positions, in one case, a minimum land size is 0.6 ha, but in others it is 1 ha. Co-owners, regardless of their particular municipality, legally being in the same position, in event of a real distribution find themselves in the different legal positions, because in case a piece of land is located in one municipality the real distribution is possible, but if a piece of land is in another - then it is not. This approach limits the rights of co-owners.

In addition, in terms of hierarchy of the laws and regulations, the binding municipal regulations are subordinated laws having a lower legal power than the Civil Law, which grants the right of co-owners to the distribution joint property. Also, from this point of view it is wrong to apply the local binding regulations in case of real distribution of joint property.

Ownership is one of the oldest public regulatory rights; it is a value with thousands of years- long traditions, while the environmental rights are a relatively new law that has developed a quantitative segment, but still does not have quality coverage. In particular, the areas affecting the rules of environmental rights have been defined, but it is not defined explicitly, "how deep" the environmental rights should provisionally regulate this or that area of legal relations. Kristīne Krūma, the Judge of the Constitutional Court, states: "Environmental protection should be an integral part of the process of the development, and it cannot be considered in isolation. Thus, in order to promote sustainable development, it is important to balance the economic development and the environmental protection."2

\footnotetext{
${ }^{1}$ See, e.g., Judgement of 16 December 2005 to the Case No 2005-12-0103 by the Constitutional Court of the Republic of Latvia. ${ }^{2}$ Separate Opinion of Kristīne Krūma, Judge of the Constitutional Court, to the Case No 2008-03-03.
} 


\section{SHS Web of Conferences}

The Constitutional Court has also recognized that the State has an obligation to reach a possibly higher level of environmental protection and the obligation to continuously improve the situation in the area of environmental protection. ${ }^{3}$ However, as concerns the issue of the right of co-owners to divide a jointly owned real estate, the author believes that the environmental legislation is an inadequate regulation to the legitimate aim pursued. The division of real estate does not in itself expose to danger the objects protected by the environmental rights. Division of an object of a property (e.g., parcels) into a number of objects does not present damage to the environment.

There is an artificially created conflict between the legal system and the value system. The ambiguity of the situation, when it comes to the solution, is characterized by the cases considered by the Constitutional Court of the Republic of Latvia about the non-conformity of the spatial planning to the Constitution of the Republic of Latvia.

Spatial planning is a means of environmental protection. The rules relating to the spatial planning are responsibilities vested with the local governments. It could be understandable, because planning takes place in a particular region and its governing institutions must hold the right to decide. There are no sufficient legal grounds that the laws applied to the spatial planning would automatically apply to all transactions related to division of real estate. Distribution of joint property does not constitute an environmental modification for the purposes of covering it with buildings or taking any activities of environmental impact, where the minimum parcel size and other requirements should be observed. Distribution of the joint property is the termination of the joint property. Motives and targets of the legal entities may differ. The private property rights of co-owners are unduly limited by the public environmental rights.

\section{Results}

As a result of the research, the author came to the following conclusions:

1) environmental laws are primarily focused on the regulation of construction (as an environmentally transformative action), in turn, the legal target of the distribution of joint property is to terminate the joint property;

2) the rules that affect and refer to the real division of real estate are different in every republican city or county municipality;

3) the real estate of land is classified by the construction criteria;

4) in the procedure of real distribution of joint property, the public law takes precedence over the civil law, leading to a substantial reduction of content property rights.

\section{Conclusions}

In the rights of co-owners to divide a jointly owned property, the intervention of environment rights is inadequate to their legislative purpose. The division of real estate in itself cannot undermine the objects protected by environmental rights.

\section{Proposals}

In order not to narrow down the rights of co-owners in the distribution of joint property under the influence of the environmental regulatory enactments, it is necessary:

1) legal provisions relating to spatial planning and to transactions involving the real distribution of an object of a joint property are not be applied automatically;

\footnotetext{
${ }^{3}$ In more detail: Judgement of 21 December 2007 of the Constitutional Court to the Case 2007-12-03, Point 21.
} 
Int. Conf. SOCIETY. HEALTH. WELFARE.

2) application of binding regulations of local authorities on spatial planning have to be reviewed in cases of real distribution of joint property;

3) in interpretation of the law, real distribution of joint property is to be considered as a means of termination of co-ownership, and the target of usage of the real estates (parcels) established as a result of such distribution should be decided after their establishment;

4) concerning the real distribution of joint property, uniform requirements throughout the country should be established by incorporating the relevant provisions in the Civil Law.

\section{References}

[1] Čepāne, I. (2011). Searching for the balance between the right to property and the favourable environment in the Constitutional Court practice. Jurista Vārds, Nr.47, 6.-8.

[2] 15.02.1922. Law "Constitution of the Republic of Latvia" ("LV", 43, 01.07.1993). [came into force 07.11.1922.] as amended.

[3] Universal Declaration of Human Rights. Available at: http://www.humanrights.lv/doc/vispaar/ vispcd.htm (accessed 29/04/2013).

[4] Convention for Protection of Human Rights and Fundamental Freedoms, First Protocol. Available at: http://www.humanrights.lv/doc/regional/eck1prot.htm (accessed 29.04.2013).

[5] Judgment of 16 December 2005 of the Constitutional Court of the Republic of Latvia to the Case No 2005-12-0103. Available at: www.satv.tiesa.gov.lv/upload/2005-12-0103.rtf (accessed 30.04.2013).

[6] Judgment of 21 December 2007 of the Constitutional Court to the Case No.2007-12-03. Available at: http://www.satv.tiesa.gov.lv/upload/spriedums_2007-12-03.htm (accessed 30.04.2013).

[7] Separate Opinion of Kristīne Krūma, Judge of the Constitutional Court, to the Case 2008-03-03 Available: http://www.satv.tiesa.gov.lv/upload/atseviskas_2008_03_03.htm (accessed 03.05.2013).

[8] 02.11.2006. Law "Environmental Protection Law” (“LV”, 183 (3551), 15.11.2006., Ziņotājs, 24, 28.12.2006). [came into force 29.11.2006.] as amended

[9] 13.10.2011 Law “Spatial Development Planning Law” (“LV”, 173 (4571), 02.11.2011.) [came into force 01.12.2011.] as amended

[10] 14.09.2006. Law "Land Survey Law" (“LV”, 157 (3525), 03.10.2006., Ziņotājs, 20, 26.10.2006). [came into force 01.01.2007.] as amended

[11] 28.01.1937. Law "Civil Law. Third part. PROPERTY RIGHTS” [came into force on 01.09.1992.] as amended

[12] 20.06.2006. Cabinet of Ministers No 496 "Classification of the targets as to the use of real estate and order of detection and change of targets of the use of real estate" ("LV", 108 (3476), 11.07.2006.) [came into force on 12.07.2006.] as amended 